\title{
$O$ papel das oferendas de alimentos na manutenção \\ do status das Esposas Divinas de Âmon (séculos VIII-VI a.C.)
}

\author{
The role of the food offerings in the maintenance \\ of the God's Wives of Amun's status $\left(8^{\text {th }}-6^{\text {th }}\right.$ centuries BC)
}

\section{André Shinity Kawaminami'}

RESUMO: O ritual de oferenda de alimentos é muito presente nas fontes egípcias e tinha como principal objetivo garantir o suprimento aos deuses e aos indivíduos falecidos. Entretanto, esse rito também foi utilizado nas representações iconográficas de algumas sacerdotisas conhecidas como "Esposas Divinas de Âmon" para manter e propagar seu poderio social, político e religioso na região de Tebas. Por meio da análise iconográfica de quatro imagens provenientes de duas capelas destinadas ao culto de Osíris em Karnak, das capelas-tumbas das esposas divinas em Medinet Habu e de um edifício residencial de uma dessas sacerdotisas em Naga Malgata, este artigo tem como objetivo analisar o papel das oferendas de alimentos na manutenção e consolidação do status das esposas divinas nos séculos VIII-VI a.C.

Palavras-chave: Egito Antigo; Esposa Divina de Âmon; oferenda de alimentos; agência; Tebas.

ABSTRACT: The food offering ritual is very present in the Egyptian resources and it had the main aim to ensure the supply to the gods and the deceased individuals. However, this rite was also utilized in the iconographic representations by some priestesses known as "the God's Wives of Amun" to keep and propagate their social, political and religious mightiness

\footnotetext{
${ }^{1}$ Mestrando em História Social pela Universidade de São Paulo (FFLCH-USP). Contato: shinityo2@gmail.com. A temática deste artigo integra o projeto de pesquisa financiado pela Fundação de Amparo à Pesquisa do Estado de São Paulo (FAPESP, processo n ${ }^{\circ}$ 2020/03090-4), intitulado Entre a Realeza e o Culto: As Esposas Divinas de Âmon (séculos XII-VI a.C.).
} 
in the region of Thebes. Through the iconographic analysis of four images from two chapels destined to the cult of Osiris in Karnak, the tomb-chapels of the god's wives in Medinet Habu and one residential edifice of one of these priestesses in Naga Malgata, this article aims to analyze the role of the food offerings in the maintenance and consolidation of the god's wives' status in the $8^{\text {th }}-6^{\text {th }}$ centuries BC.

Keywords: Ancient Egypt; God's Wife of Amun; food offering; agency; Thebes.

\section{Introdução}

No Egito Antigo, era muito comum que alimentos fossem oferecidos em contextos funerários. Este ritual, conhecido como "oferenda de alimentos", aparece desde o início da história faraônica e era destinado principalmente à garantia do suprimento aos falecidos no pós-morte e/ou à manutenção da harmonia advinda dos deuses. Entretanto, a complexidade dessa prática poderia se expandir para outras questões religiosas, culturais, sociais e políticas. É o caso das representações iconográficas das esposas divinas de Âmon em que elas aparecem realizando oferendas de alimentos em diferentes ocasiões.

Levando em consideração a proeminência, a agência e o status das esposas divinas enquanto sacerdotisas em suas representações nos relevos iconográficos e a presença neles do rito de oferenda de alimentos aos deuses ou para elas mesmas, este artigo tem como objetivo analisar como esse ritual foi utilizado pelas esposas divinas na manutenção de suas agências social, política e religiosa e de seu status. Para tanto, serão examinadas, por meio da análise iconográfica e com base no conceito de agência derivado da teoria antropológica da arte de Alfred Cell, quatro imagens de proveniências distintas em que essas sacerdotisas são retratadas concedendo ou recebendo alimentos.

O segundo item do artigo apresenta um breve quadro panorâmico sobre o ofício de Esposa Divina de Âmon. Em seguida, são abordados alguns dos alimentos mais representados nas fontes egípcias e as mesas de oferenda, assim como seus significados e 
suas implicações. No quarto item, são tratados os aparatos teórico-metodológicos utilizados na análise das fontes - que é desenvolvida no quinto item do artigo. Por fim, o sexto e último item consiste nas considerações finais sobre a problemática abordada.

\section{O ofício de Esposa Divina de Âmon}

$\mathrm{Na}$ história do Egito Antigo, houve alguns períodos em que uma categoria de sacerdotisas do culto do deus Âmon se tornou muito importante e proeminente na região de Tebas. Essas mulheres, portadoras do título de "Esposa Divina de Âmon”, eram responsáveis por realizar diversos rituais aos deuses, como oferecer alimentos, vinho e Maat $^{2}$, tocar sistros ${ }^{3}$ e inaugurar monumentos. Elas foram amplamente representadas na cultura material egípcia em Karnak, Medinet Habu e Naga Malgata em posições de destaque e, muitas vezes, excepcionais quando comparadas ao cânone artístico egípcio.

A criação desse ofício na hierarquia sacerdotal de Âmon no início do Reino Novo (c. 1550-1069 a.C.) estava ligada a uma negociação de poder entre a realeza egípcia e o sacerdócio dessa divindade. Devido ao crescimento da autoridade e influência política que o culto de Âmon estava obtendo cada vez mais desde o final do Segundo Período Intermediário (c. 1650-1550 a.C.), o faraó Ahmose (c. 1552-1527 a.C.) criou o ofício de "Esposa Divina de Âmon" e tornou sua esposa, Ahmose-Nefertari, a primeira mulher a portar esse título (AYAD, 2009a, p. 4-6).

Depois de Ahmose-Nefertari, o título é utilizado ocasionalmente por outras rainhas até a 20 dinastia (c. 1186-1069 a.C.). É a partir de Ísis, filha do rei Ramsés VI (c. 1143-1136 a.C.), que o ofício passou a ser ocupado não mais por esposas dos faraós, mas sim por princesas. Inicia-se, então, a tradição de as esposas divinas não poderem contrair matrimônio e gerar herdeiros, devendo permanecer casadas apenas com o deus Âmon (COSSELIN, 2007, p. 193). ${ }^{4}$

\footnotetext{
2 "Maat" era um conceito de ordem, justiça e equilíbrio centralizado em uma deusa com o mesmo nome (AYAD, 2009a, p. 61).

${ }^{3}$ Instrumento musical que era utilizado com o objetivo de estimular os deuses sexualmente ou para representar a ideia de concessão e geração de vida. No caso das esposas divinas, devemos associá-lo mais com o ideal de concessão de vida do que com a intenção de estimular os deuses sexualmente (AYAD, 2009a, p. 51).

${ }^{4}$ Apesar de ainda ser uma ideia bastante defendida dentro da Egiptologia junto da suposição de que elas eram virgens, é necessário ter cautela com a questão de as esposas divinas poderem contrair matrimônio ou não dado que houve a influência de concepções ocidentais e cristão-judaicas na interpretação desse ofício desde o final do século XIX. Além disso, há vestígios nas fontes egípcias de que algumas dessas sacerdotisas (que vieram depois de Ísis) foram casadas também com outros indivíduos (TEETER, 1999).
} 
Após o final do Reino Novo inicia-se o Terceiro Período Intermediário (c. 1069-664 a.C.), momento em que o Egito passou por uma nova descentralização política, pelo crescimento do poder dos Altos Sacerdotes de Âmon e pela migração e desenvolvimento da autonomia dos líbios em seu território. São estes que iniciam a $22^{\text {a }}$ dinastia (c. $945-715$ a.C.) com o reinado de Sheshonq I. Nesse período, o ofício de esposa divina foi preservado e, segundo Ayad (2009a, p. 15), atingiu o seu ápice de poder político, simbólico e religioso, com a nomeação de Shepenwepet I (c. 754-714 a.C.) ao cargo pelo seu pai e faraó Osorkon III. A partir dela, as esposas divinas foram amplamente representadas em capelas funerárias em Karnak e em suas capelas-tumbas em Medinet Habu. Ademais, elas foram responsáveis e estiveram envolvidas na construção de diversos monumentos na região de Tebas (BLYTH, 2006, p. 190-192), como em Naga Malgata - onde ficavam os seus edifícios residenciais.

Com a invasão núbia do Egito em 716 a.C., encerra-se o governo líbio e Shabaqo (c. 716-702 a.C.) torna-se faraó, anexando o Egito ao reino de Kush e inaugurando a $25^{\mathrm{a}}$ dinastia (c. 747-656 a.C.). Mesmo com essa mudança real, o ofício de Esposa Divina de Âmon foi mantido, crescendo em importância e status (TAYLOR, 2000, p. 331-332). Do período de regência núbia, temos duas esposas divinas proeminentes: Amenirdis I (c. 740-700 a.C.) e Shepenwepet II (c. 710-650 a.C.).

Entre 671 e 663 a.C., a $25^{\text {a }}$ dinastia termina com a invasão dos assírios. Necau I (c. 672664 a.C.), em nome e sob proteção destes, ascende como faraó e dá início à $26^{\text {a }}$ dinastia (c. 664-525 a.C.) (LLOYD, 2000, p. 365-366). Seu sucessor, Psamético I (c. 664-610 a.C.), indicou sua filha Nitócris (c. 556-586 a.C.) como a próxima esposa divina depois das sacerdotisas núbias e, assim, assegurou a continuidade e o funcionamento do ofício. A última esposa divina foi Ankhnesneferibre (c. 595-525 a.C.), que se manteve no cargo até o período da Primeira Dominação Persa (c. 525-404 a.C) - momento em que o ofício foi extinto.

Ao nos debruçarmos sobre os ritos realizados por essas mulheres que foram representados nas fontes egípcias, é possível notar uma grande presença de oferendas de alimentos. Esse ritual tinha uma importância simbólica e religiosa que advém desde o início da história do Egito Antigo. Seu principal objetivo era fornecer alimentos aos deuses e/ou aos falecidos no pós-morte. Entretanto, esse rito também envolvia procedimentos nas suas representações, nas quais a posição dos envolvidos e o que e como se oferecia são muito relevantes para apreender as relações políticas, religiosas e sociais egípcias. 
Para compreender as oferendas de alimentos nesse sentido, é necessário analisar como esse rito era entendido na concepção dos egípcios antigos, como eram as suas representações e quais elementos eram retratados nessa prática.

\section{Os alimentos e as mesas de oferendas no Egito Antigo}

Os alimentos, de maneira geral, aparecem constantemente nas fontes egípcias, tanto materiais como textuais, principalmente nos contextos funerários. É nas tumbas e capelas que mais aparecem representadas imagens de refeições, réplicas e listas de oferendas de alimentos, processos de fabricação de comidas e bebidas, sua conservação e consumo e os próprios alimentos físicos que eram concedidos ao morto. Nesses locais, é possível encontrar também mesas próprias para o depósito de gêneros alimentícios que eram destinados ao proveito do beneficiário no além. Em suma, é no contexto funerário que encontramos a maior parte das fontes sobre a alimentação no Egito Antigo e como ela era pensada e moldada em relação ao pós-morte.

Graças à variedade das fontes que dispomos hoje, podemos delinear a alimentação egípcia e o que nela era mais valorizado-e, portanto, mais desejável de ser representado nas oferendas. De maneira geral, os egípcios alimentavam-se principalmente de grãos, verduras e legumes. Boa parte da população não possuía acesso frequente a frutas e a alguns tipos de carne vermelha. Havia o consumo de diferentes tipos de pães feitos de cevada e trigo e também de cerveja (CAMA-ROLLAND, 2019, p. 78-80).

Sobre as frutas (como uvas, tâmaras e figos) e as carnes de algumas espécies (como a de bovídeos), ambas eram consideradas artigos luxuosos. Quanto aos alimentos de origem animal (os quais, com exceção dos peixes, não eram frequentemente consumidos pelas classes mais baixas), os egípcios antigos possuíam uma grande variedade de tipos de carne, como a de cabras, antílopes, patos, porcos e bovídeos (estes eram considerados os mais apreciados pela realeza e a elite). Ainda sobre as proteínas, havia a presença de uma diversidade de peixes na dieta egípcia, consumidos por todas as camadas da população. Os egípcios também ingeriam leite (de vaca, cabra e asna) e seus derivados - ainda que não seja tão claro quais camadas sociais desfrutavam desses alimentos. Havia ainda o consumo de vinho, mesmo que ele fosse limitado a uma pequena parcela da sociedade (GAMAROLLAND, 2019, p. 78-90). 
No contexto funerário, as oferendas de alimentos possuíam significados específicos para a sociedade egípcia. Como atestado a partir de tumbas do período Pré-Dinástico (c. 5300-3000 a.C.), o próprio ato de concedê-los aos mortos perdurou durante toda a história do Egito Antigo. De modo geral, a oferenda de comidas e bebidas aos deuses tinha como objetivo apaziguá-los, agradecê-los e/ou pedir a manutenção da ordem e prosperidade em vida. No caso das oferendas aos falecidos, elas tinham como objetivo principal fornecer aquilo que seria necessário para eles se alimentarem no mundo dos mortos. Nas tumbas, as mesas destinadas à concessão de alimentos eram muito comuns e eram geralmente representadas em imagens e/ou dispostas fisicamente em locais acessíveis para que, assim, os alimentos fossem trazidos por visitantes ou sacerdotes funerários. As comidas e bebidas poderiam também ser parcialmente consumidas em banquetes por aqueles que faziam as visitas - mantendo, assim, o morto no interior da sociedade dos vivos. Dessa forma, por meio de um conjunto de representações relacionadas à alimentação, garantia-se o que estava sendo concedido mágica e eternamente aos mortos (ENCLUND, 2001, p. 564-566).

Em suma, oferecer alimentos aos deuses e aos mortos era um elemento essencial na concepção de mundo egípcia. No caso das representações das esposas divinas em relevos iconográficos, parte considerável delas conta com a presença de comidas e bebidas que elas concediam aos deuses ou para outras sacerdotisas da mesma categoria.

\section{O tratamento das fontes: os alimentos, as imagens, o contexto funerário e o conceito de agência}

Antes de apresentar propriamente os métodos de análise deste artigo, é preciso fazer algumas ressalvas quanto ao tratamento dos alimentos em si presentes nos relevos iconográficos. O estado das fontes selecionadas não permite sempre a total compreensão de quais itens eram representados nas cenas - o que dificulta suas identificações e análises específicas. Por meio das formas dos elementos retratados, é possível, de maneira geral, separá-los entre legumes, verduras, frutas, pães e carnes. Mesmo que possamos identificar uma ave em uma mesa de alimentos, por exemplo, lidamos com outra dificuldade (a qual se estende a quase todos os alimentos): os egípcios consumiam diversos tipos de aves e, dentro desse grupo de animais, diferentes espécies de patos e gansos - o que torna árduo e, muitas vezes, inviável o processo de separá-los e precisá-los baseado nas características 
representadas, não permitindo um delineamento do sentido específico que tal espécie teria em uma cena. Assim, reconhecendo esse problema, este artigo limita-se a uma análise mais geral dos significados dos alimentos, procurando não estabelecer uma listagem de todos os itens representados e suas especificidades e sim dedicar-se ao que é identificável e mais significativo para a problemática abordada.

Neste artigo, os alimentos serão considerados como um elemento portador de processos de construção social, cultural e identitária. Isto significa ter no horizonte de análise que as comidas e bebidas são mais do que objetos alimentícios: elas também são agentes e representantes de diferentes tipos de relações sociais. Os alimentos estão inseridos em uma rede de sentidos e podem nos ajudar a compreender não apenas os seus significados para a sociedade egípcia, mas também como eles articulam-se em diferentes tipos de discurso para a constituição da mensagem que se desejava transmitir em uma determinada fonte. Desse modo, os alimentos serão tratados com um enfoque voltado mais para o âmbito cultural - ou seja, eles serão entendidos como vetores de ação social e política e as práticas que os envolvem como "espaços de articulação de sentidos, valores, mentalidades etc." (MENESES; CARNEIRO, 1997, p. 17).

Para a análise dos relevos iconográficos selecionados, será procurado o jogo social que as suas imagens pressupõem e elas serão entendidas como "artefatos" - antes de uma abstração, as imagens também constituem objetos materiais, o que levanta questões sobre suas trajetórias enquanto cultura material e a agência social da imagem (MENESES, 2005, p. 50-52). Nesse sentido, para o tratamento das fontes será feito um exercício de "desdocumentalização", como proposto por Ulpiano Meneses: para recuperar as diversas trajetórias dos relevos iconográficos, devemos desconstruí-los enquanto documento para projetá-los nos seus ciclos sociais originais, ou seja, nos seus próprios contextos (de produção, circulação etc.). Dessa forma, é possível pensarmos no seu papel histórico e nas suas relações com a sociedade (MENESES, 1983, p. 110).

Sobre a questão da agência, este conceito - derivado da teoria antropológica da arte de Alfred Gell - pode nos ajudar a compreender a forma com que determinada sociedade se relacionava com sua cultura material. Para Cell, "agência" é a capacidade de algo agir, produzir efeito sobre alguma coisa em uma relação de causa e efeito e de fazer com que determinados eventos ocorram em torno de si. Esse conceito pode ser atribuído tanto a pessoas como a coisas, desde que elas sejam consideradas como iniciadoras de sequências 
causais. Assim, há uma "agência social", que pode ser exercida em relação a objetos como também por objetos (GELL, 2018, p. 45-47).

No caso das imagens selecionadas, é importante levar em consideração que três delas encontram-se em contextos funerários. Esse tipo de ambiente no mundo egípcio antigo deve ser compreendido como um espaço de natureza liminar, que ocupava uma posição instável e ambígua entre duas esferas de existência (o reino dos vivos e o dos mortos). Os programas de decoração funerária possuem projetos de naturezas distintas que corporizam redes de intencionalidade (PEREIRA, 2019, p. 103-104). Isto significa que, mais do que um ponto de contato entre os vivos e os mortos e entre os mortos e os deuses (PEREIRA, 2019, p. 88), os contextos funerários devem ser entendidos também como manifestações de projetos políticos, religiosos, sociais e culturais.

Quanto às inscrições e aos textos que acompanham as imagens selecionadas, eles serão integrados à análise de forma secundária quando possível - pois o difícil acesso às suas transliterações e traduções, assim como a visibilidade prejudicada dos textos hieroglíficos nas fotografias/desenhos das fontes, tornam uma análise conjuntural de texto e representação visual (no caso dos relevos selecionados neste artigo) inviável. Portanto, reconhecendo essa limitação, o foco da análise recairá, sobretudo, nas imagens dos relevos em si.

Levando tudo isso em consideração, o tratamento das fontes procurará seguir o seguinte roteiro: em um primeiro momento, será realizada uma desconstrução da fonte enquanto artefato, tentando inseri-la em seus contextos originais para delinear sua rede de interações sociais; em seguida, será feita uma análise descritiva e estrutural da representação visual, procurando destrinchá-la e traduzir seus possíveis significados visuais; por fim, será feita uma análise conjuntural das imagens para entender suas agências.

\section{A relação das esposas divinas com as oferendas de alimentos}

Como citado anteriormente, quatro imagens serão analisadas. A primeira delas trata-se de um relevo iconográfico encontrada na capela de Osíris, Governante da Eternidade (Heqa-djet); a segunda encontra-se na Capela de Osíris, Aquele que está no meio da Árvore Persea (Wennefer Hery-ib-pa-ished) (ambas as capelas encontram-se no leste de Karnak, próximas do Templo de Âmon-Rá); a terceira está localizada nas capelas-tumbas das esposas 
divinas em Medinet Habu; e, por fim, a quarta imagem está presente em uma parede do Edifício de Colunas de Nitócris, em Naga Malgata.

\subsection{A capela de Osíris, Governante da Eternidade}

A capela de Osíris, Governante da Eternidade, é a primeira de uma série de outras que foram construídas pelas esposas divinas de Âmon da $23^{\mathrm{a}}-26^{\mathrm{a}}$ dinastias a leste e ao norte do Templo de Âmon-Rá em Karnak. Essas capelas eram dedicadas ao culto do deus Osíris em suas variadas formas e aspectos (como definem os títulos que constituem seus nomes), mas também ao culto de outros deuses, como Âmon. Não sabemos exatamente sobre a circulação de pessoas nesses edifícios, o que dificulta a recuperação da trajetória e do alcance que o programa decorativo teve e a agência em si do edifício. Entretanto, as representações egípcias de maneira geral (visuais e textuais) possuíam um forte teor mítico-mágico, o que fazia com que não houvesse uma separação como entendemos hoje entre a realidade do mundo físico e o que estava na imagem (PEREIRA, 2019, p. 60). Nesse sentido, os relevos iconográficos e o que era retratado neles, por exemplo, possuíam uma agência apenas pela sua existência dentro do programa decorativo em que eles se situavam, dando "vida" e perpetuando as ideias, vontades e conceitos que eram neles representados.

No caso da capela de Osíris, Governante da Eternidade, ela possui três salas, um pátio com colunas e um portão de entrada. Ela foi construída inicialmente no governo dos faraós líbios Osorkon III e Takeloth III, momento em que Shepenwepet I era a esposa divina em exercício, e recebeu algumas alterações em sua estrutura no reinado do faraó núbio Shebtiko (c. 707-690 a.C.) - quando Amenirdis I assumiu o ofício (AYAD, 2009b, p. 29). Nesse monumento, Shepenwepet é a esposa divina mais retratada, tocando sistros para os deuses, consagrando oferendas de alimentos, sendo amamentada pelas deusas Hathor e SemetWeret e sendo coroada pelo deus Âmon.

Ao analisarmos o conjunto de suas representações, o papel primário desempenhado por Shepenwepet nesta capela pode ser considerado o de realizar oferendas aos deuses. Ela é retratada 15 vezes neste rito - o que ultrapassa o número de cenas no local que retratam os faraós. Assim, é possível considerar que o status de esposa divina de Âmon era o mais prestigiado no programa de decoração desse monumento. Não apenas pela quantidade de 
aparições, mas também pelo tamanho em que elas são representadas e pelos ritos e suas posições nestes que eram realizados aos deuses.

A primeira imagem a ser analisada encontra-se na parte leste da fachada original de arenito da capela (Figura 1). Neste relevo, Shepenwepet é retratada em perfil, com sua face voltada à esquerda da imagem, diante de três divindades: Âmon-Rá, Rá-Horakhty e Ptah (da direita para esquerda, respectivamente). A sacerdotisa utiliza um vestido com mangas longas e soltas, com uma faixa em camadas amarrada sobre sua cintura. Ela porta um colare uma coroa elaborada (danificada por conta da ação do tempo sobre o relevo) que permanece acima de sua pequena peruca. Em suas mãos, ela segura dois sistros, os quais ela toca para o benefício dos três deuses.

Voltado em direção à esposa divina, Âmon-Rá, o mais próximo de Shepenwepet, estende para ela um $a n k h^{5}$, segurando-o pela sua mão esquerda. Este deus porta uma coroa de penas duplas (insígnia habitual de Âmon), uma barba falsa curvada, um colar e um saiote amarrado junto de uma cauda cerimonial de touro em sua parte de trás. Um cetro ouas ${ }^{6}$ está $^{2}$ verticalmente posicionado também em sua mão esquerda, que o separa de Shepenwepet. Em sua outra mão, o deus porta outro ankh.

Atrás de Âmon-Rá está Rá-Horakhty, que é representado em uma posição idêntica à de Âmon. Como este, a divindade possui um colar e um saiote com uma cauda de touro. Um disco solar está presente no topo de sua longa peruca. Seguido de Rá-Horakhty está a estátua de Ptah, representado de pé sobre um pedestal, com um manto envolvendo seu corpo. $\mathrm{O}$ deus também segura em seus punhos um cetro ouas.

Do lado direito da imagem, atrás de Shepenwepet, há uma elaborada mesa de oferendas repleta de diversos tipos de frutas e vegetais, incluindo pães, carnes (como a de pato) e flores de lótus (AYAD, 2009b, p. 33). Na extrema direita da cena, ao lado da mesa, Osorkon III (identificado pelas inscrições ao seu lado), consagra os alimentos. Representado em perfil, com sua face voltada à esquerda, ele estende com sua mão direita um cetro hetes ${ }^{7}$ em direção aos alimentos. Em sua outra mão ele carrega um cetro hed ${ }^{8}$ e um cajado. Ele usa uma coroa branca do Alto Egito e um saiote cerimonial tripartite.

\footnotetext{
${ }^{5}$ Símbolo que representava "vida" (PETERS-DESTÉRACT, 2003, p. 364).

${ }^{6}$ Longo bastão cuja extremidade superior era ornamentada por uma cabeça de animal com orelhas longas enquanto sua extremidade inferior era bifurcada. Este objeto, reservado aos deuses, representava força e poder (PETERS-DESTÉRACT, 2003, p. 376).

7 Um dos cetros utilizados na consagração de oferendas (GRAHAM, 2001, p. 165).

${ }^{8}$ Cetro no formato de maça que servia para atacar os inimigos do Egito (PETERS-DESTÉRACT, 2003, p. 369).
} 


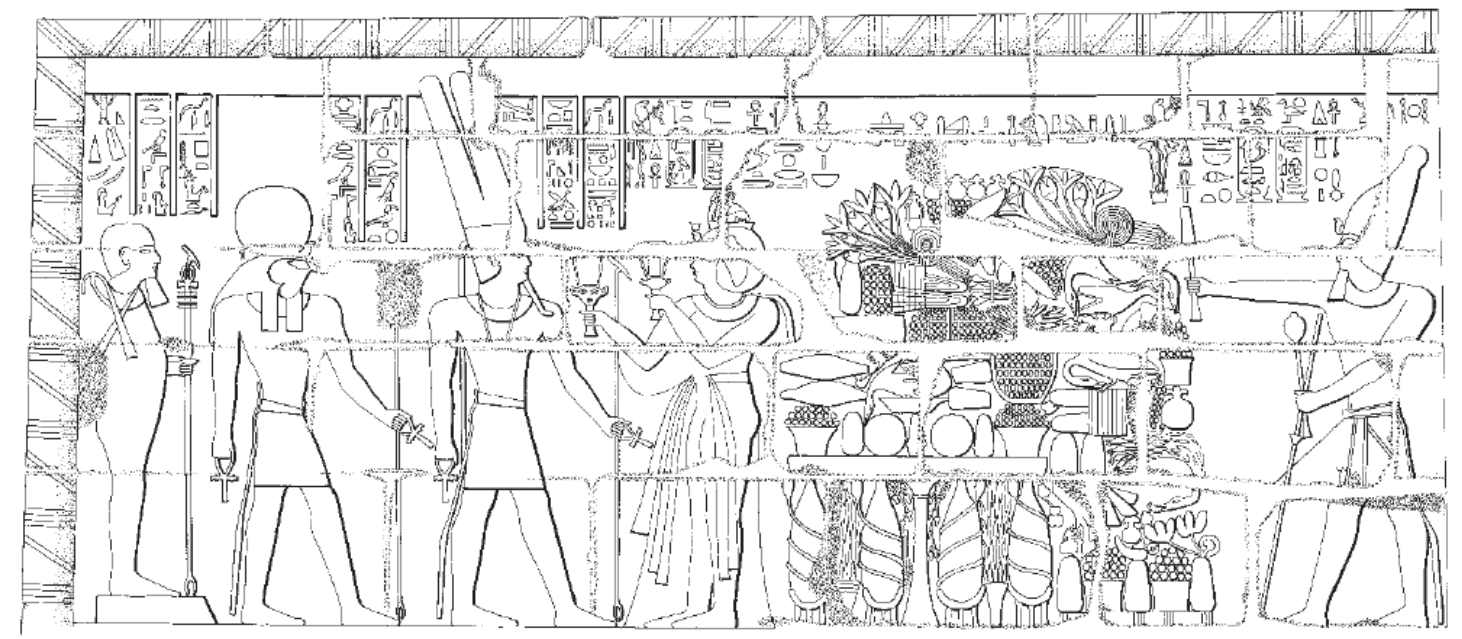

Figura 1: Shepenwepet I toca sistros para Âmon-Rá, Rá-Horakhty e Ptah, enquanto Osorkon III consagra uma mesa de oferendas. Fonte: Redford (2004, p. 68).

Sobre os alimentos presentes, é notável a presença das flores de lótus. O lótus aquático era uma das plantas mais comuns nas representações egípcias e sua flor possuía um papel proeminente naquela cultura: ela simbolizava o sol e o eterno ressurgimento da vida (suas pétalas fecham-se de noite e reabrem no início do dia). Ela era um símbolo relacionado aos deuses e também representava o sul do Egito, sendo o papiro a planta que representava o norte (DARBY; GHALIOUGUI; GRIVETTI, 1977, p. 621). Além dos significados simbólicos, o lótus também era utilizado pelos egípcios para fins alimentares (CAMA-ROLLAND, 2019, p. 79).

A oferenda das flores de lótus aos deuses pode ser entendida como uma forma de enriquecer o conjunto daquilo que estava sendo concedido. Com a presença abundante de alimentos diversos, as flores complementavam a mesa e adicionavam um peso simbólico ligado ao divino e à eternidade para as oferendas. Dessa forma, o status do que era oferecido aos deuses aumentava e, em consequência, também o de quem estava envolvido no rito.

Neste relevo, a mesa de oferendas de alimentos, em um primeiro momento, pode ser tomada como uma divisão da representação em duas partes. Na sua parte esquerda, temos a esposa divina interagindo com os três deuses ao tocar sistros, enquanto que na sua direita, o faraó consagra às divindades as oferendas. Esses dois ritos tinham como alvo os deuses, para que, assim, fossem mantidas a paz, a concessão de vida e a ordem no mundo egípcio (AYAD, 2009b, p. 33). Entretanto, a disposição de Shepenwepet na imagem é significativa quando pensamos nas tradições de representação artística do cânone egípcio. 
O fato de a esposa divina estar mais próxima dos deuses do que o faraó nesse contexto e de ser representada no mesmo tamanho que eles é algo excepcional na iconografia egípcia. Sua proximidade em relação às divindades é mais ressaltada pela distância que separa o rei egípcio delas, criada, em parte, pela mesa de oferendas - localizada entre ela e Osorkon III, ao invés de entre ela e os deuses. Esse arranjo particular pode indicar duas hipóteses: a primeira é de que a cena tratava de dois ritos realizados separadamente, que ocorreram seguidamente começando pelo ato de tocar sistros e terminando com a consagração das oferendas. A segunda hipótese é de que Shepenwepet e seu pai foram representados realizando os rituais simultaneamente. Levando em consideração a segunda hipótese e o cânone artístico egípcio, o rei é quem deveria ter sido colocado mais próximo dos deuses, não a esposa divina (AYAD, 2009b, p. 33-34).

Estar a esposa divina mais próxima dos deuses do que o faraó nos indica a diferenciação que as primeiras adquiriram simbólica e socialmente no contexto funerário egípcio e nos leva a refletir sobre um status característico e excepcional que elas alcançaram. Na primeira imagem, dois ritos distintos são realizados por Shepenwepet e pelo faraó. Não havia necessariamente uma qualificação de superioridade entre a essência dos dois rituais (ambos possuíam objetivos, em primeira instância, distintos). Entretanto, a posição ocupada pela sacerdotisa é significativa na constituição de sua agência no âmbito da sua relação com o divino e em relação à autoridade resguardada pelo rei egípcio nesse campo. A mesa de alimentos, mais do que uma divisão intencional ou não na imagem para o destaque do status da esposa divina, é um rito importante a ponto de ser representado em um contexto em que aparecem três divindades, uma esposa divina e o faraó. Além de ser destinada a alimentar os deuses e, assim, manter a ordem e equilíbrio, ela possui neste relevo um papel excepcional na relação das esposas divinas com os deuses e a realeza.

\subsection{A capela de Osíris, Aquele que está no meio da Árvore Persea}

A segunda imagem está localizada na parede sul do hall da capela de Osíris, Aquele que está no meio da Árvore Persea (Figura 2). A mesma esposa divina que aparece na imagem anterior, Shepenwepet I, é retratada oferecendo alimentos para o deus Âmon e a deusa Mut, todos representados de perfil. Do lado direito da imagem, com seu braço direito dobrado e estendido em direção às divindades, a sacerdotisa utiliza uma coroa de penas duplas, um 
uraeus $^{9}$ em sua testa e um colar. O estado do relevo registrado pela sua fotografia não permite um delineamento exato da vestimenta que ela está usando. Em sua mão esquerda, Shepenwepet segura os cetros hetes e hed, os mesmos utilizados por Osorkon III na primeira imagem para consagrar as oferendas. Em sua frente, encontra-se uma mesa de oferendas com alimentos, sendo os mais identificáveis pães, a perna de um bovídeo e peixes.

Do outro lado da mesa, à esquerda da imagem, estão os dois deuses voltados em direção à esposa divina. Âmon porta uma coroa de penas duplas, uma barba falsa curvada, um colar, um peitoral e um saiote. Sua mão esquerda está estendida em direção à mesa de oferendas, segurando um cetro ouas, enquanto a sua mão direita segura um ankh. Atrás dele, Mut está com seu braço esquerdo colocado nas costas de Âmon, enquanto que em sua mão direita ela também porta um ankh. Ela está utilizando as coroas branca e vermelha do Alto e Baixo Egito, uma peruca de abutre ${ }^{10}$ e um tipo de vestimenta que se assemelha à de Shepenwepet.

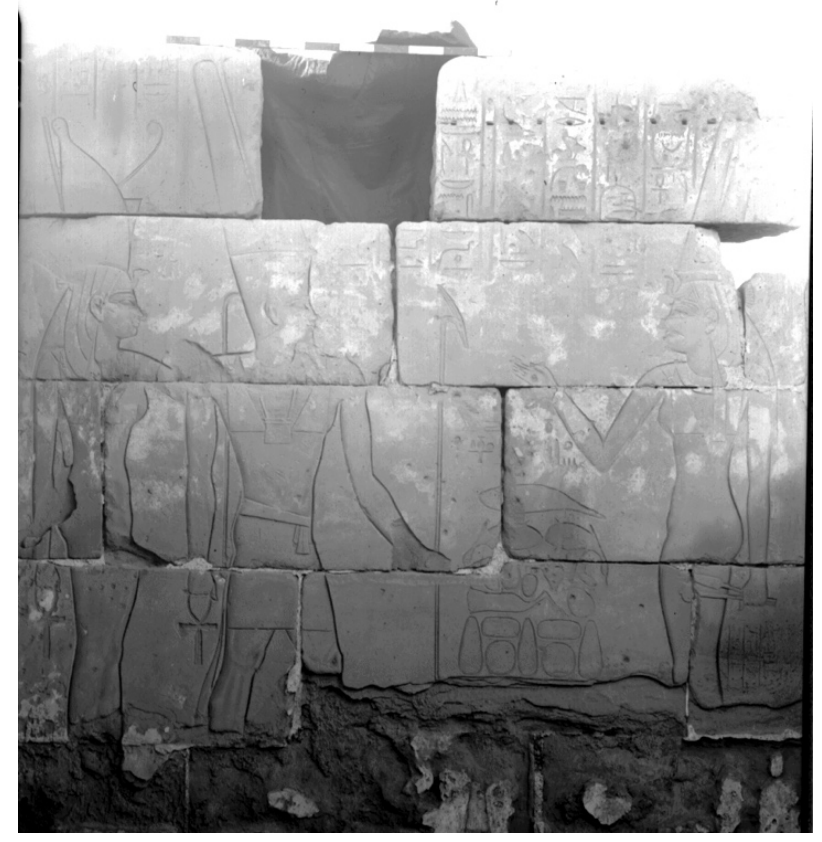

Figura 2: Shepenwepet I oferece alimentos para Âmon e Mut. Fonte: Instituto Oriental de Chicago, Epigraphic Survey Negative 8617.

Ao possuir o mesmo tamanho que os dois deuses, a esposa divina reafirma seu status excepcional nos contextos de representação com divindades. Portando a mesma coroa que a

\footnotetext{
${ }^{9} \mathrm{O}$ uraeus era uma naja ou cobra, representada com o seu pescoço ereto. Esse símbolo aparece muitas vezes na frente de coroas ou de perucas de indivíduos ligados à realeza e tinha como objetivo protegê-los e eliminar seus inimigos (PETERS-DESTÉRACT, 2003, p. 379).

${ }^{10}$ Este ornamento era utilizado comumente pelas rainhas, por vezes colocado de baixo de uma coroa. A cabeça do abutre está posicionada de forma semelhante à do uraeus (PETERS-DESTÉRACT, 2003, p. 364).
} 
de Âmon e os mesmos cetros utilizados por Osorkon em outra capela, Shepenwepet consagra a oferenda de alimentos para os dois deuses. Nesse caso, a mesa de oferenda em questão tem um papel direto na constituição da agência da sacerdotisa, pois ela é utilizada no ritual de concessão de alimentos aos deuses com Shepenwepet portando insígnias que a legitimam e somam ao seu tamanho equivalente ao das divindades. Ademais, os alimentos que foram representados sobre a mesa também têm participação no rito em si e na manutenção do status da esposa divina. Um deles é a perna de um bovídeo. Como colocado anteriormente, a carne bovina era um artigo de luxo, sendo um item mais voltado às elites e à realeza. Sua aparição na mesa influencia no valor do que estava sendo concedido aos deuses, aumentando o prestígio das oferendas e da relação estabelecida entre aquele que recebe e aquele que concede. Dessa forma, podemos pensar que aquele que consagrava o conjunto de alimentos estimados beneficiava-se ainda mais do ritual e do retorno esperado dos deuses.

\subsection{As capelas-tumbas em Medinet Habu}

Diferentemente das duas imagens anteriores, a terceira encontra-se ao lado oeste do rio Nilo, em Medinet Habu. Neste local, as esposas divinas Shepenwepet I, Amenirdis, Shepenwepet II, Nitócris e Ankhnesneferibre teriam sido enterradas em suas capelastumbas. Essas capelas foram dispostas estruturalmente em uma sequência, juntas, com suas fachadas voltadas de frente para o Pequeno Templo de Âmon. Nesse monumento, há a presença de corredores e portas no interior das construções, interligando-as e, quanto à sua estrutura física, apenas as capelas-tumbas de Amenirdis e Shepenwepet II foram feitas de pedra - sendo elas, portanto, as mais bem preservadas. As outras duas consistem em sua maior parte de muros de argila - o que provavelmente fez com que elas se deteriorassem mais rápido (HÖLSCHER, 1954, p. 18).

A imagem selecionada neste edifício encontra-se na parte direita da fachada da capela de Nitócris, Shepenwepet e Mehetnusekhet (apesar de não ser uma esposa divina e sim a mãe biológica de Nitócris - portanto, uma rainha -, ela foi enterrada nesta capela). Neste relevo, há uma representação em que Shepenwepet II é retratada recebendo alimentos como oferenda por Nitócris, sua herdeira e sucessora no ofício (Figura 3). Esta, à direita da imagem, é representada portando uma coroa de penas duplas e um vestido longo, 
com o braço direito dobrado estendido em direção à mesa de oferendas. Em sua mão direita, a esposa divina segura um ankh. À sua frente, está uma mesa com alimentos, dos quais podemos identificar pães, verduras e um pedaço de uma perna de boi. Do lado esquerdo da imagem, está Shepenwepet II, portando uma coroa igual à de Nitócris, uma peruca de abutre, um colar e um vestido longo. Em sua mão direita, a sacerdotisa segura também um ankh, enquanto na sua mão esquerda, com o braço junto de seu peito, ela segura um cetro flexível ${ }^{11}$. Ao oferecer uma ampla variedade de alimentos (incluindo os considerados mais prestigiados) para sua predecessora, Nitócris reafirma por meio desse ritual o status e agência das esposas divinas de Âmon e a continuidade do ofício.

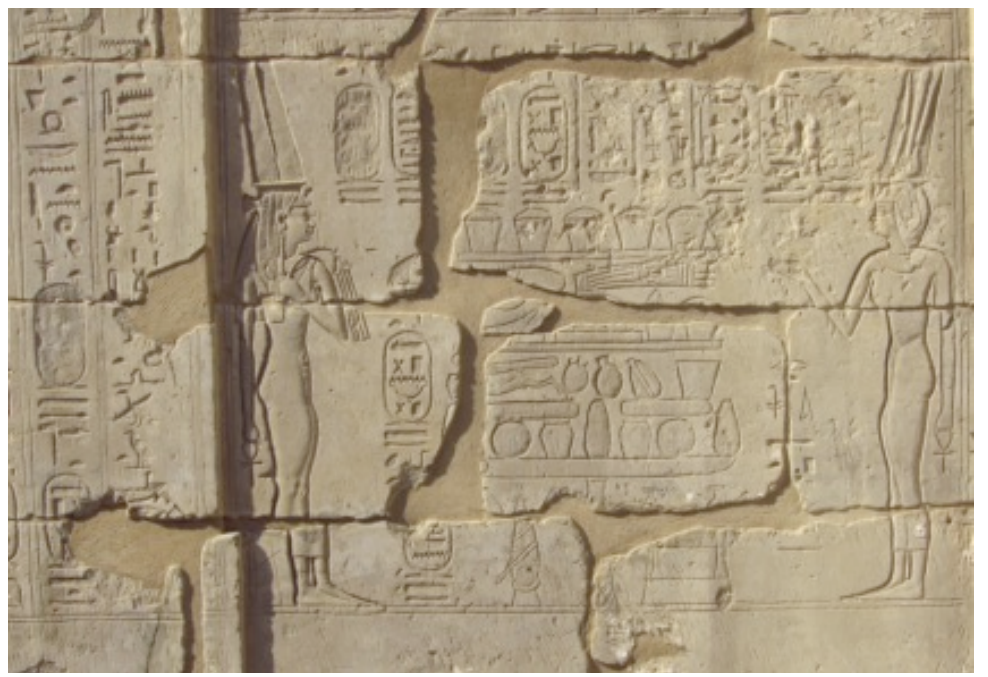

Figura 3: Nitócris oferece alimentos para Shepenwepet II. Fonte: Coulon (2018, p. 280).

\subsection{O Edifício de Colunas de Nitócris em Naga Malgata}

A quarta imagem está localizada em Naga Malgata, no chamado Edifício de Colunas de Nitócris. Naga Malgata é o nome atual de uma vila que corresponde ao antigo quarteirão residencial das esposas divinas em Karnak, ao norte do recinto de Âmon e a oeste do recinto de Mut. Apesar de os monumentos relacionados às sacerdotisas neste local estarem em sua maior parte destruídos, é possível reconstruí-los parcialmente pelos vestígios arqueológicos e fontes diversas da região (COULON, 2014, p. 565-566).

Na parede leste do interior do edifício de Nitócris, esta esposa divina é representada acompanhada de Ibi, seu Chefe Administrador, recebendo oferendas de alimentos (Figura

\footnotetext{
${ }^{11}$ Este cetro é característico das esposas reais, o qual era segurado contra o peito e com a sua ponta pendendo sobre um dos ombros (PETERS-DESTÉRACT, 2003, p. 377).
} 
4). Não obstante o estado danificado do relevo, é possível identificar os dois ao lado esquerdo da imagem. Ibi ocupa o lado mais extremo da cena, atrás da esposa divina. Ele utiliza um saiote, segura algo contra seu peito com sua mão esquerda e foi retratado em um tamanho menor que o da esposa divina. Em sua frente está Nitócris, sentada em um trono que está em cima de um pedestal. Ela utiliza uma coroa que provavelmente, pelo formato, é a de penas duplas, um vestido longo e segura algo não identificável em sua mão esquerda, que está sobre seu peito, enquanto sua mão direita repousa sobre seu colo.

No centro da imagem, é possível identificar uma grande mesa de alimentos composta principalmente por pães e carnes, como a bovina e a de um antílope. Acima da mesa, as inscrições consistem principalmente em uma lista de oferenda dos alimentos (MOSS; PORTER, 1972, p. 19). Do lado direito da imagem, próximo da mesa, está um sacerdote que concede as oferendas, com o braço direito estendido em direção a ela.

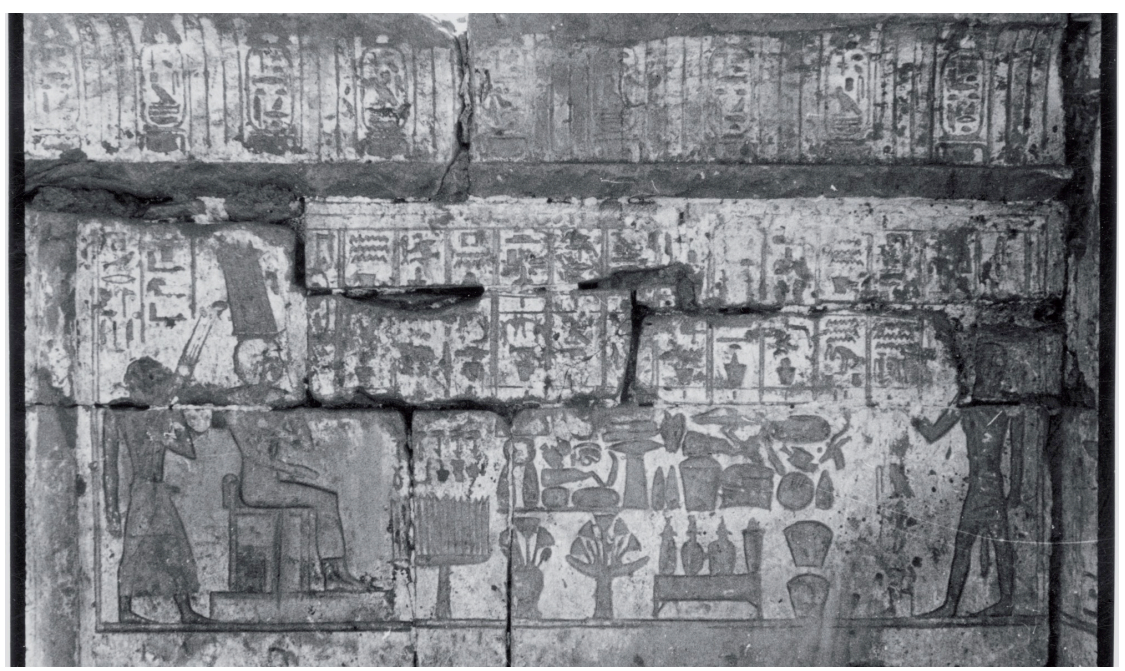

Figura 4: Nitócris, junto de Ibi, recebe alimentos como oferenda. Fonte: Coulon e Laisney (2015, p. 149).

Dos alimentos oferecidos, destaca-se a cabeça de um antílope (ponta direita superior da mesa). Por ser uma proteína de um animal selvagem, podemos pensar que o procedimento de caça para a obtenção da carne desse animal influenciava positivamente em seu status como alimento concedido - nesse caso, considerado de luxo, assim como a carne bovina.

Em um contexto não funerário, Nitócris é representada como a maior em relação aos dois indivíduos ligados ao culto de Âmon. Ao receber as oferendas no relevo em seu edifício, Nitócris dá continuidade a uma tradição de representação das esposas divinas que se manifesta nas capelas de Osíris em Karnak e em Medinet Habu. Na perpetuação do status 
excepcional do ofício, o ritual de oferendas de alimentos é notável pela quantidade de vezes em que ele é representado com essas mulheres e pela função que ele desempenha nos relevos. Para além do ato da oferenda em si com o objetivo de garantir os alimentos para os deuses ou para elas mesmas, esse rito servia para legitimar o status que elas possuíam enquanto sacerdotisas de Âmon e para aumentar o prestígio de sua relação com os deuses por meio da presença de itens de luxo incluídos no que era concedido. O ritual também demonstrava uma abundância do que estava sendo entregue e a mesa de oferendas poderia desempenhar um papel divisório na imagem, separando as esposas divinas do faraó e as colocando como as mais próximas dos deuses.

\section{Considerações finais}

Por meio da análise das quatro imagens provenientes de contextos distintos, é possível notar que as mesas de oferendas de alimentos desempenharam um papel importante na manutenção de status e agências social, política e religiosa que as esposas divinas de Âmon tiveram na região de Tebas. Esse ritual servia não apenas para garantir a ordem e alimentação dos deuses, nem somente para assegurar o suprimento das esposas divinas antecessoras. $\mathrm{O}$ rito e a escolha dos alimentos representados também serviam para propagar o poderio dessas sacerdotisas, fortalecer a relação entre elas, estabelecer seu destaque na sua relação com o divino e também para distingui-las e priorizá-las enquanto intermediadoras dos homens e dos deuses, colocando-se por vezes à frente do faraó nesse papel.

\section{Referências}

AYAD, Mariam. God's Wife, God's Servant: The God's Wife of Amun (c. 740-525 BC). Nova York: Routledge, 2009a.

AYAD, Mariam. The Transition from Libyan to Nubian Rule: The Role of the Cod's Wife of Amun. In: BROEKMAN, Gerard; DEMARÉE, Robert; KAPER, Olaf (ed.). The Libyan Period in Egypt: Historical and Cultural Studies into the 21th-24th Dynasties. Leiden: Nederlands Instituut Voor Het Nabije Oosten, 2009b. 
BLYTH, Elizabeth. Karnak: Evolution of a Temple. Nova York: Routledge, 2006.

COULON, Laurent. The Quarter of the Divine Adoratrices at Karnak (Naga Malgata) during the Twenty-Sixth Dynasty: Some Hitherto Unpublished Epigraphic Material. In: PISCHIKOVA, Elena; BUDKA, Julia; GRIFFIN, Kenneth (ed.). Thebes in the First Millennium BC. Newcastle upon Tyne: Cambridge Scholars Publishing, 2014, p. 565-586. COULON, Laurent. Les divines adoratrices à Thèbes: La construction d'une dynastie. In: COMBERT-MEURICE, Florence; PAYRAUDEAU, Frédéric (ed.). Servir les dieux d'Égypte: Divines adoratrices, chanteuses et prêtres d'Amon à Thèbes. Grenoble: Somogy Éditions D'Art, 2018

COULON, Laurent; LAISNEY, Damien. Les édifices de divines adoratrices Nitorcris et

Ânkhnesnéferibrê au nord-ouest des temples de Karnak (Secteur de Naga Malgata). Cahiers de Karnak, v. 15, p. 81-171, 2015.

DARBY, William; GHALIOUNGUI, Paul; GRIVETTI, Louis. Food: The Gift of Osiris, v. 2. Londres: Academic Press, 1977.

ENGLUND, Gertie. Offerings: An Overview. In: REDFORD, Donald (org.). The Oxford Encyclopedia of Ancient Egypt, v. 2. Nova York: Oxford University Press, 2001.

GAMA-ROLLAND, Cintia Alfieri. Alimentação e tabus alimentares no Egito Antigo. Mare

Nostrum, v. 10, n. 1, p. 77-91, 2019.

GELL, Alfred. Arte e agência. São Paulo: Ubu Editora, 2018.

GOSSELIN, L. Les Divines Épouses d'Amon dans l'Égypte de la XIXème à la XXIème dynastie. Paris: Cybele, 2007.

GRAHAM, Geoffrey. Insignias. In: REDFORD, Donald (org.). The Oxford Encyclopedia of Ancient Egypt, v. 2. Nova York: Oxford University Press, 2001.

HÖLSCHER, Uvo. The Excavation of Medinet Habu: The Post-Ramesside Remains, v. 5.

Chicago: Oriental Institute of the University of Chicago, 1954.

LLOYD, Alan. The Late Period (664-332 BC). In: SHAW, Ian (ed.). The Oxford History of Ancient Egypt. Nova York: Oxford University Press, 2000

MENESES, Ulpiano T. Bezerra de. A cultura material no estudo das sociedades antigas.

Revista de História, n. 115, p. 103-117, 1983.

MENESES, Ulpiano T. Bezerra de. Rumo a uma "História Visual". In: ECKERT, Cornelia; MARTINS, José de Souza; NOVAES, Sylvia (org.). 0 imaginário e o poético nas Ciências Sociais. Bauru: Edusc, 2005, p. 33-56. 
MENESES, Ulpiano T. Bezerra de; CARNEIRO, Henrique Soares. A história da alimentação: balizas historiográficas. Anais do Museu Paulista, v. 5, p. 9-91, 1997.

MOSS, Rosalind; PORTER, Bertha. Topographical Bibliography of Ancient Egyptian

Hieroglyphic Texts, Reliefs, and Paintings: II. Theban Temples. Oxford: Clarendon Press, 1972.

PEREIRA, Ronaldo. Texto, imagem e retórica visual na arte funerária egípcia. Rio de Janeiro: Autografia, 2019.

PETERS-DESTÉRACT, Madeleine. Clossaire. In: PETERS-DESTÉRACT, Madeleine. Abou Simbel -À la gloire de Ramsès. Mônaco: Éditions du Rocher, 2003.

REDFORD, Donald. The Sudan Invades Egypt. In: REDFORD, Donald. From Slave to Pharaoh:

The Black Experience of Ancient Egypt. Baltimore: Johns Hopkins University Press, 2004, p. $65-71$.

TAYLOR, John. The Third Intermediate Period (1069-664 BC). In: SHAW, Ian (ed.). The Oxford History of Ancient Egypt. Nova York: Oxford University Press, 2000.

TEETER, Emily. Celibacy and Adoption among Cods' Wives of Amun and Singers in the Temple of Amun: Re-examination of the Evidence. In: LARSON, John; TEETER, Emily (ed.). Gold of Praise: Studies on Ancient Egypt in Honor of Edward F. Wente. Chicago: The University of Chicago, 1999, p. 405-414. 